Articles

\title{
Undergraduate Education in Public Opinion
}

Thomas R Marshall

Keywords: survey practice

DOI: $10.29115 /$ SP-2010-0005

\section{Survey Practice}

Vol. 3, Issue 1, 2010

Undergraduate Education in Public Opinion

Although public opinion is a well established profession with a long-standing interest in students' education (Baxter 1971; Groves 1996), little is known on how the field is taught to undergraduates. This article examines undergraduate education at U.S. colleges and universities on four questions: the number and range of courses in public opinion and survey research, where courses are taught, what topics are taught, and the number of undergraduates annually enrolled in these courses.

Undergraduate courses are identified through a stratified list sample, breaking U.S. colleges and universities into three strata: larger public universities (those with 10,000 or more students); smaller public universities and colleges (fewer than 10,000 students); and private universities and colleges. This list is from the 2006-2007 Accredited Institutions of Postsecondary Education (Washington D.C.: American Council on Education, ed., Kenneth A. Von Alt). This article samples schools within the 50 American states (and D.C.), excluding schools without a reported enrollment, and vocational, technical, and specialized colleges and institutes, such as art, architecture, automotive, fashion, paralegal, sports, medical, culinary, court reporting schools, and seminaries. Excluded schools typically have small enrollments, and a spot check indicates no public opinion courses.

A total of 213 schools are sampled within three strata, including 72 schools in the first, 71 in the second, and 70 in the third strata, by picking a random initial start point and a skip interval within each stratum. In the descriptions below, mid-sized public schools are further broken down into two groups: those with enrollments of 5,000 to 10,000 students, and those with smaller enrollments. For instructional hours and enrollment estimates, below, the strata are re-weighted to their correct numbers.

Within American colleges and universities, public opinion and survey research courses are located in several academic departments and listed under a variety 
of titles. To identify courses, on-line college catalogs (available for all these schools) were searched for common key words in course titles, such as "public opinion", "polling”, "survey research" or "propaganda". Course listings were also searched for political science, sociology, media/communications/ journalism, education, psychology, statistics, and marketing departments or social science groupings.

Syllabi were collected from February through April 2009 from university web sites and from e-mail or telephone calls to professors who teach these courses. Annual enrollments were collected by contacting the professor. Syllabi were collected for 84 percent of identified courses. Annual enrollment figures were collected for 57 percent of identified courses.

These results are for "stand-alone" classes - those in which half or more of the class deals with the public opinion and survey research topics described below. Courses that only briefly cover public opinion and survey research are not counted as a stand-alone class, thus excluding many classes such as introductory American government or sociology classes. No marketing courses or statistics classes are included, since none of these syllabi identifies a class in which public opinion or survey research is half or more of the course.

\section{HOW MANY CLASSES ARE OFFERED?}

Stand-alone courses in public opinion and survey research are now taught at a wide variety of American colleges and universities. Large public universities (those with over 10,000 students) are the most likely to offer such classes; most (71 percent) of such schools offer at least one class, with an average of 1.33 classes offered. A third (31 percent) of mid-size public universities and community colleges (those with 5,000 to 10,000 students) offer at least one class, averaging .34 classes. Far fewer courses are offered at smaller public universities and colleges (those with fewer than 5,000 students); only six percent of such schools offer a class, averaging .07 classes. Private schools fall between these extremes; a third (33 percent) of private schools offer at least one class, averaging . 43 classes. The number of courses offered is strongly correlated (at 0.01) with a school's total enrollment. Region, urban location, and (for private schools only) religious affiliation are not significantly (at 0.05 ) related to the number of courses offered.

\section{WHERE ARE CLASSES OFFERED?}

Political science departments are the most common home for public opinion and survey research courses. At larger public schools $59 \%$ of political science departments offer at least one class, compared to only $13 \%$ of sociology departments and $21 \%$ of journalism/communications/media departments. At mid-size public schools these figures are $25 \%, 8 \%$, and $6 \%$, respectively. At private schools the figures are $30 \%, 3 \%$, and $8 \%$, respectively. At smaller public schools, departmental structure is less clearly defined and too few courses are offered for meaningful analysis. Only a handful of stand-alone courses appear 
outside these three departments.

\section{WHAT'S TAUGHT, WHAT'S NOT?}

The current or most recent syllabus was obtained for 84 percent of these courses, either from the school's web site or from the department or professor offering the course. Syllabi vary widely in their detail, length, and format, but nearly all include a week-by-week or class-by-class schedule with topics and readings. Individual topics are converted to instructional hours, if necessary from textbook assignments. Instructional hours average just over 40 hours per course, excluding examinations. Course content descriptions, below, are based entirely on syllabi. Because there is no consistent sequence of topics across syllabi, minimal bias may result if professors do not follow or fall behind on the syllabi.

Each syllabus is broken down by ten topics, and as to whether a research paper or a hands-on polling project is required (Table 1). Across all courses, the three topics covered at greatest length are statistics and sampling theory, attitudes, and the impact of public opinion on American politics. At the other extreme, the history and background of public opinion, and ethics, law, and professional standards receive the fewest instructional hours. Because courses vary greatly by department, Table One also reports average instructional hours for the three departments most often offering classes. 
Table 1 Average Instructional Hours of Undergraduate Classes by Topic.

\section{Course Topic}

History and background

Ethics, law, standards

Various types of surveys

Attitudes - theories, types, knowledge, specific topics

Impact of public opinion democracy, representation

Sources of public opinion - individuals, groups, events, eras (but not mass media)

\section{Mass media}

Statistics, sampling theory

Specific survey problems, questions, questionnaires

Data resources, class reports and presentations

Require a paper?

Hands-on survey experience?

$\begin{array}{llll}\text { Overall } & \text { Political Science } & \text { Sociology } & \begin{array}{l}\text { Journalism/ } \\ \text { Communications }\end{array} \\ 1.7 & 2.1 & 0.2 & 1.5 \\ 0.4 & 0.1 & 1.0 & 1.5 \\ 3.1 & 2.1 & 7.3 & 4.3 \\ 7.8 & 9.9 & 1.6 & 6.0 \\ 7.4 & 9.9 & 0.2 & 4.2 \\ 3.9 & 5.0 & 0.4 & 4.4 \\ 2.3 & 2.6 & 0.2 & 4.6 \\ 8.1 & 4.0 & 16.4 & 11.7 \\ 3.5 & 2.8 & 6.0 & 3.0 \\ 2.8 & 2.3 & 8.1 & 0.2 \\ 65 \% & 67 \% & 10 \% & 67 \% \\ 15 \% & 11 \% & 30 \% & 12 \%\end{array}$


Two-thirds (65 percent) of courses require a term paper, but only 15 percent require hands-on survey experience. Why hands-on polling experience is so rare is unclear. Possibly, it was never common. Possibly, student involvement in hands-on survey projects fell victim to students' time demands and the practical difficulties of carrying out surveys.

\section{WHAT'S THE UNDERGRADUATE ENROLLMENT?}

Finally, how many undergraduates annually enroll in public opinion and survey research classes? This estimate results from multiplying the total number of schools by the average number of courses offered, that figure multiplied by the average annual enrollment, individually for each strata, and then by combining these totals across the three strata. This leads to an estimate of 22,670 students annually enrolled in public opinion courses, further broken down as 9,576 students in larger public state universities; 3,608 students in mid-size and smaller public schools; and 9,486 students in private schools. This figure includes neither graduate enrollments nor the (doubtlessly much larger) number of students who are exposed to a lecture or two on public opinion in classes such as introductory government, sociology, or journalism classes.

From one perspective, this estimate may seem small, with considerable room for enrollment growth. Nonetheless, this estimate is larger than for other areas of study (Funk and Sears 1991). Over a decade, more than two hundred thousand American undergraduates take a course in public opinion and survey research. These enrollments not only encourage future graduate students and career professionals, but also provide a basis for the American public's understanding of and appreciation for survey research.

\section{ACKNOWLEDGMENTS}

The author is grateful to Kimberly Caraway Harper for providing research assistance and to the University of Texas at Arlington for supporting this project. 


\section{REFERENCES}

Baxter, R.H. 1971. "Presidential Address: A New Goal for AAPOR.” Public Opinion Quarterly 35 (3): $430-35$.

Funk, C.L., and D.O. Sears. 1991. "Are We Reaching Undergraduates? A Survey of Course Offerings in Political Psychology." Political Psychology 12 (3): 559-72.

Groves, R.M. 1996. "Presidential Address: The Educational Infrastructure of the Survey Research Profession.” Public Opinion Quarterly 60 (3): 477-90. 